\title{
OUTCOME OF MULTIVISCERAL ECHINOCOCCOSIS: A CASE REPORT
}

\author{
Hajric Zlata, ${ }^{1}$ Pasic Amela, ${ }^{2}$ Spahic Razija ${ }^{2}$ \\ ${ }^{1}$ Children's Department, General Hospital, Tesanj, Bosnia and Herzegovina \\ ${ }^{2}$ Children's Hospital, University Clinical Center Tuzla, Bosnia and Herzegovina
}

Primljen/Received 03. 05. 2017. god.

Abstract: Introduction: The pathogen of multivisceral echinococcosis is the same agent as for single-organ echinococcosis: Echinococcus granulosus.According to the consensus of experts under the aegis of the WHO-IWGE - WHO-Informal Working Group on Echinococcosis options of treatment should be: (1) percutaneous treatment, (2) surgery, (3) anti-infective drug treatment or (4) watch and waitapproach or combinations thereof.

Case report: The presented case was a sevenyear-old Caucasian boy, a permanent resident of rural region near Tuzla, Bosnia and Herzegovina, who had a history of asymptomatic giant liver and small lung hydatid cyst (multivisceral echinococcosis). We consider that the patient was in the phase of secondary hydatidosis even before undergoing the first treatment PAIR method of liver and continued with adjunctive chemotherapy. Two weeks after discharge, during the adjunctive chemotherapy he had one of possible complication where pre-existed smal lung hydatid cyst got inflamed and performed an abscess mass and potential septic risk, which required surgical and antibiotic treatment. Surgery and early postoperative course were normal and the patient was discharged with recommendation to continue with previously started adjunctive chemotherapy (Albendazol) according to treatment protocol.

Conclusion: Most infected persons are asymptomatic and clinical manifestations vary according to the anatomic location of the cyst, so we want to indicate the importance of routine ultrasound screening of preschool children, and eventually $\mathrm{X}$ ray chest scan.This case report highlights the necessity of caution with choosing appropriate treatment, even though size of cyst can be irrelevant to take surgical treatment in first line instead of medical therapy.

Key words: echinococcosis, hydatid cyst, hydatidosis, diagnosis, treatment.
Prihvaćen/Accepted 13. 06. 2017. god.

\section{INTRODUCTION}

Hydatid disease (cystic echinococcosis) is aparasitic infestation caused by Echinococcus species, the most common being Echinococcus granulosus; others are E. multilocularis and E. vogeli. The primary hosts are dogs while humans are accidental intermediate hosts infected through ingestion of contaminated food with dog faeces or through direct contact with dogs (1).

On the contrary to the popular perception, hydatidosis (cystic echinococcosis) does not remain restricted to endemic geographical locales anymore but is rather a global health concern, particularly in the rural countryside and semiurban localities. Most of the cases of hydatid disease come from rural areas or from people who have settled in urban localities after spending a majority of their life in villages. Many patients usually acquire the disease during childhood, but do not present with the clinical signs and symptoms until late adulthood (2).

The pathogen of multivisceral echinococcosis is the same agent as for single-organ echinococcosis: Echinococcus granulosus. During its lifecycle, humans are intermediate hosts in which only the larva, the hydatid cyst, with different localizations, develops. Multivisceral echinococcosis is defined as the simultaneous localization of the hydatid cysts in more than one viscera. It was differentiated it from multiple echinococcosis, which means multiple localizations of the hydatid cysts inside the same viscera. The most frequently involved organs were: lungs, liver, spleen, heart, thoracic aorta, pancreas, and the kidneys. More frequent multivisceral associations were: right lung - left lung; left lung - liver; right lung - liver (3).

Errors in the clinical diagnosis of hydatid disease are frequent due to the lack of any typicalclinical presentation of the disease and imaging features which 
can also be variable. The symptoms of hydatid disease depend onwhich organs are affected. Most patients with hydatid cysts are asymptomatic, and the diagnosisis usually made incidentally during clinical radiological examination for unrelated reasons (4).

The variation of clinical presentation depends on the size and site of the lesion as well as the accessibility of the organ involved in the clinical examination. Lung involvement with chest pain, cough, shortness of breath can cause non specific symptoms such as fever and hemoptysis (5).

Diagnosis is based on clinical signs, laboratory resultsand epidemiologic data (6).

The combined use of ultrasonography and immunodiagnosis makes possible the distinction of echinococcal cysts from benign cysts, abcesses or malignant neoplasms (7).

The standard chest X-ray is very useful and it can suggest by itself the diagnosis of pleuro-pulmonary echinococcosis. Around or oval opacity, of subcostal intensity is described. According to evolutionary stage of the hydatid cyst, the radiological aspect is described as polymorphic. The introduction of computed tomography in the diagnosis of multivisceral echinococcosis brought immense advantages. Computed tomography is useful in certifying multivisceral echinococcosis diagnosis, differential diagnosis and postoperative surveillance (3).

For cystic echinococcosis, the consensus of experts under the aegis of the WHO-IWGE - WHO-Informal Working Group on Echinococcosis, has been obtained on an image-based, stage-specific approach, which is helpful for choosing one of the following options: (1) percutaneous treatment, (2) surgery, (3) anti-infective drug treatment or (4) watch and wait approach or combinations there of. Clinical decision-making depends also on setting-specific aspects. The usage of an imaging-based classification system is highly recommended (8). It is useful to establish a concept that defines multivisceral echinococcosis and guides the therapeutic management of multivisceral hydatid disease.

\section{CASE PRESENTATION}

A seven-year-old Caucasian boy, a permanent resident of rural region near Tuzla, Bosnia and Herzegovina, presented to us for the first time with asymptomatic liver cyst found by routine ultrasound screening. He was admitted with normal vital signs and normal physical examination apart from the occurrence of herpes labialis. Laboratory investigations that were performed included a complete blood count, liver function tests and urine analysis; all results were within normal ranges. CT scan of abdomen revealed a round cystic for-

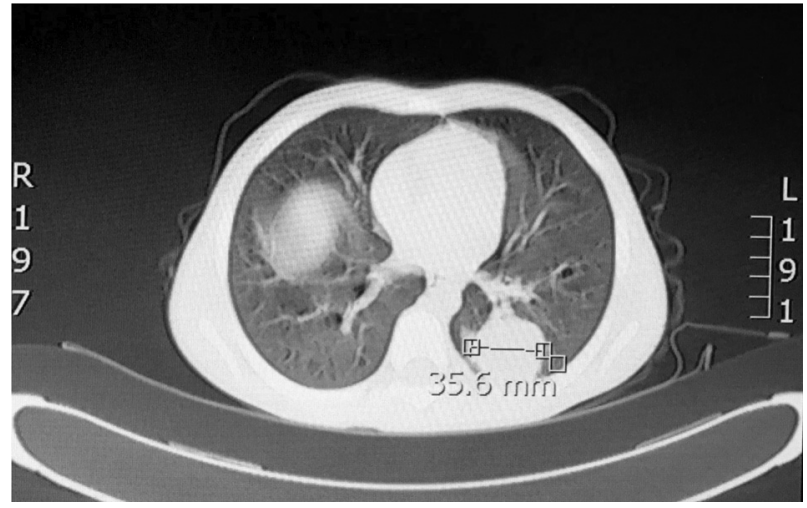

Figure 1. Cystic formation in left basal lung

mation dimension 120x100 mm in right lobe of liver. On (CT) scan of the thorax was also revealed cystic formation cca $35 \mathrm{~mm}$ in diameter in left basal lung (Figure 1). CT scan of endocranium was normal. Serological test results for echinococcus were negative.

Therefore, according to asymptomatic clinical state of child, it was decided that liver cyst was treated with PAIR method (puncture, aspiration, injection, reaspiration) while lung cyst due to the size was left to treat conservatively with albendazole ( $15 \mathrm{mg} / \mathrm{kgday})$ and regular follow up.PAIR confirms the diagnosis and removes parasitic material.

Twelve days after discharge he was admitted to hospital again reporting fever, cough and haemoptysis. His vital signs were as follows: body temperature, 36.8 degrees Celsius; blood pressure, 110/60 mmHg; heart rate, $88 / \mathrm{min}$; and respiratory rate, 20 breaths $/ \mathrm{min}$. Pulmonary examinations revealed decreased breath sounds. The rest of physical examinations except herpes labialis and pharyngitis were normal. Laboratory investigation was as follows: elevated Erythrocyte sedimentation ratio (ESR), 116/120, C-Reactive protein (CRP), 188,8 mg/l; with leukocytosis and neutrophilia, elevated IgE $622 \mathrm{IU} / \mathrm{ml}$ (normal for age $<200 \mathrm{IU} / \mathrm{ml}$ ), elevated D dimer $0,8 \mathrm{mg} / 1$ (0-0,55 mg/), flow cytometry showed low number of Natural Killer cells. Serological tests for Echinococcus granulosus were positive (ELISA and IHA). Sputum, bronchoalveolar aspirate and aspirate of cyst were negative for Ecinococcus in direct microscopic analysis and cultures while sputum was positive for Candida albicans.

Chest CT scan identified necrotizing pneumonia with progression into pulmonary abscess, 50x60mm, of left basal lung where previously small cyst was described with communication to lobar bronchus (Figure 2), while CT of abdomen showed hepatic cyst in regression. Preexisting echinococcus cyst of left basal lung which is partly evacuated and inflammed could not be excluded as differential diagnosis.

He was treated with a course of broad spectrum antibiotics, antifungal drugs and albendazole as an ant- 


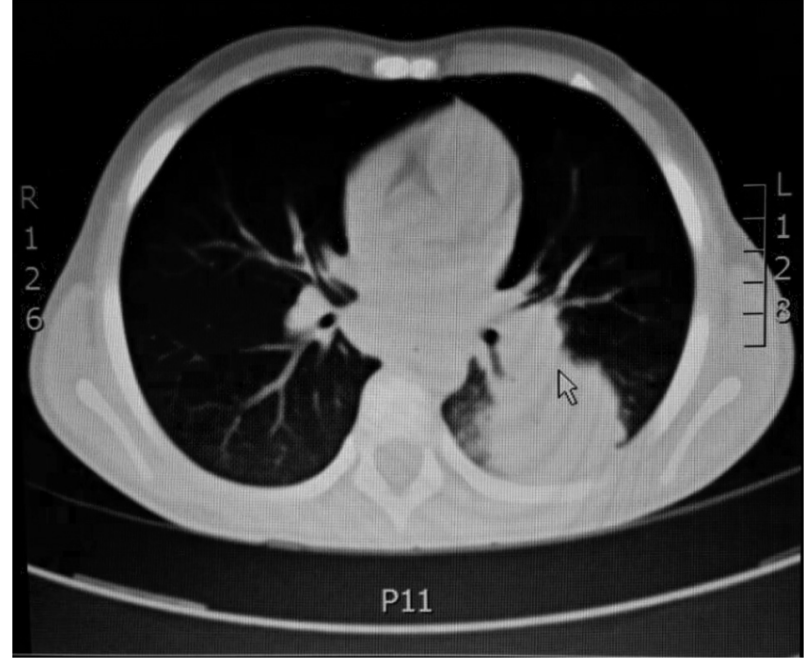

Figure 2. CT scan shows pulmonary abscess of pre-existing cyst with communication to lobar bronchus

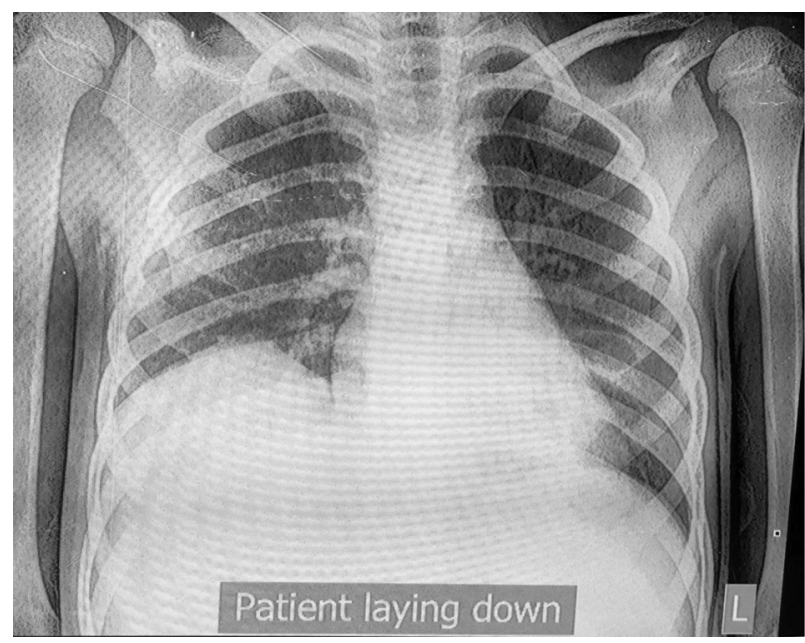

Figure 3. Chest X ray after finished treatment

helmintic. Operative evacuation of abscess was performed. His postoperative recovery was uneventful. Chest drain was removed by fourth postoperative day. He was discharge on the seventh day after surgery. Adjunctive chemotherapy with oral albendazole (200 mg twice daily) was administrated for two more weeks total of 4 weeks in second cycles of treatment of hydatid cyst. Chest X ray after finished treatment (Figure 3).

\section{DISCUSSION}

The presented case has a history of asymptomaticgiant liver and small lung hydatid cyst (multivisceral echinococcosis). We consider that the patient was in the phase of secondary hydatidosis even before undergoing the first treatment PAIR method of liver and continued with adjunctive chemotherapy. Our theoryis based on the existence of a small pulmonary cyst with fluid and solid tisue partially calcified walls, as it being known that calcium needs time to accumulate. This case illustrates the extremely complex nature hydatidosis may present, being a rareform of disseminated multivisceral disease with complications (infected hydatid cyst with secondary abscess and potential septic risk).

In study of Arif et al. did though there is not much evidence on the subject, anecdotally, surgeons describe softening and decrease in turgidity of large hydatid cysts with medical therapy (9). According to Sumontra in his article of case report where 29 year woman had surgical treatment of two large lung cysts and continued adjunctive treatment with albendazol of liver cyst, during her recovery and 6 weeks after resection had rupture liver cyst. So given the almost simultaneous change in both cysts, they have postulated that the perioperative antiparasitic therapy for the pulmonary cyst may have been a contributor to the rupture of the large hepatic cysts (10).

Echinococcus granulosus involvement in children has a different pattern than adults. In adults, liver is the most common site of localization of the larval forms whilst in children it is more common in the lungs (2). For our case is more important to analyze frequency of combined liver/lung cysts in endemic regions.In study which did Djuricic et al in Serbia during 17 years period identified that involvement of combined liver/lung cysts in patients were $6,0 \%$ (11). Authors from Romania revealed that the hepatic localization of the hydatid cyst $(50.51 \%)$ among children was more common than pulmonary localization (16.49\%) and liver and lung localization was found in $22.16 \%$ of cases (12). Paredes $\mathrm{S}$ et al. in their article of case report and literature review, had conslusion that hepatopulmonary hydatidosis is an unusual entity in children (13). Authors from Serbia Djuricic et al. in their study during period of 1998-2010 found that the number of cases in children continuously decreased over the period (14).

C. Grozavu et al in their study after the analysis of clinical material and studying all 84 cases of multivisceral echinococcosis, from all included locations of the hydatid cysts they have found for our study singificancy 22 cases ( $26.19 \%$ ) as left lung and liver location (3).

Most infected persons are asymptomatic and clinical manifestations vary according to the anatomic location of the cyst(15). The natural progression of untreated cyst may include calcification and death of the cyst, however, more frequently, the cyst gradually enlarges in size (16). Hydatid cyst fluid is highly allergenic and carries a risk of anaphylaxis, thus the intraperitoneal rupture of a hydatid cyst is a life threatening emergency that can be potentially fatal (17).

Medical treatment (chemotherapy) with benzimidazole-like drugs has indication for multivisceral echinococcosis perioperatively or between seriate surgeries $(18,19)$. 
According to Grozavu et al. they do not recommend medical treatment as first therapeutic step because it could lead to serious complications, like suppurations with lung parenchyma destruction. Drug therapy has a certain curative effect on cysts smaller than two $\mathrm{cm}$. Their patients did not have any relapses after medical treatment. Conservative methods involve saving the pericyst (residual cavity) after extracting and removing the parasite. These techniques are used for patients with high surgical risk: localization of hydatid cyst is hard to access, patient's comorbidities contraindicates the surgical intervention, etc.PAIR This procedure consists of puncture (P), aspiration (A), injection of parasiticid agent (I), re-aspiration or reinjection (R). It can be applied through percutaneous approach, minimally invasive, or through open surgery.

Surgical treatment of human echinococcosis is based on conservative (salvaging as much tissue or parenchyma as possible) or more aggressive procedures (removing more tissue or parenchyma along with the cyst). First priority is the surgical treatment of complicated cysts (infection, fistula, hemorrhage) no matter their localization. The second priority are uncomplicated cysts with thoracic localization because any general anesthesia can rupture the hydatid cysts with secondary pulmonary infection. Finally, the third priority is the size of the cyst - larger cysts will be removed before smaller cysts (3). Grozavu et al recommend classic surgery with minimal loss of visceral parenchyma. The surgical treatment of multivisceral echinococcosis can be simultaneous (in a single surgical intervention) or successive (seriate surgical interventions). Simultaneous attack can be accomplished through a single approach (neighbouring locations) or through separate approaches (distant locations).

Regarding the order of surgical interventions, they have established that it is determined by several priorities, as stated above (3).

Although surgery still remains the most common approach for treatment of CE throughout the world, long-term albendazole therapy has significant efficacy in approximately $70 \%$ of cases (21).

A post-treatment follow-up method to prognostically determine the efficacy of treatment should therefore include markers that allow the detection of newly growing or relapsing cysts and the tracking of previously undetected but still viable cysts. Conventional tools used to follow-up cystic echinococcosis patients include imaging techniques such as X-ray, ultrasono- graphy, computed tomography, and magnetic resonance imaging (22).

\section{CONCLUSION}

Most infected persons are asymptomatic and clinical manifestations vary according to the anatomic location of the cyst, so we want to incidicate the importance of routine ultrasound screening of preschool children, and eventually $\mathrm{X}$ ray chest scan.

The aim of this paper was to present a multivisceral echinococcosis and one of its possible complication. The asymptomatic patient was diagnosed to have a liver cyst and left lobe pulmonary cyst. He had undergone PAIR treatment of liver cyst and anti-infective drug treatment and follow-up. We describe complication of hydatid disease where lung cyst had been infected and became life threatening risk of sepsis.

This case report highlights the necessity of being caution with choosing treatment, sometimes even though size of cyst can be irrelevant in making a decision to start the treatment with surgery instead of only medical therapy. This confirms that suggested treatment by Godoku in our case would have been a better option, if we did not choose medical treatment of lung cysts as a first line treatment instead of surgical treatment.

According to the fact that Echinococcosis (hydatidosis) is traditionally endemic in Southeast Europe, Bosnia and Herzegovina included, epidemiological studies of CE, especially pediatric, are rare. Therefore, this article points the need and significance of one large pediatric epidemiological study of CE in Meditteriaen region should be done which could have impact on awarness of appropriate treatment with less long term complications.

\section{FINANCIAL SUPPORT AND SPONSORSHIP}

\author{
Nil.
}

\section{CONFLICT OF INTEREST}

The authors declare that there is no conflict of interest.

\section{Licensing}

This work is licensed under a Creative Commons Attribution 4.0 International (CC BY 4.0) License. 


\title{
Sažetak
}

\section{ISHOD MULTIVISCERALNE EHINOKOKOZE - PRIKAZ SLUČAJA}

\author{
Hajric Zlata, ${ }^{1}$ Pasic Amela, ${ }^{2}$ Spahic Razija ${ }^{2}$ \\ ${ }^{1}$ Children's Department, General Hospital, Tesanj, Bosnia and Herzegovina \\ ${ }^{2}$ Children's Hospital, University Clinical Center Tuzla, Bosnia and Herzegovina
}

Uvod: Patogeni agens koji izaziva multiviscearlnu ehinokokozu je isti kao i onaj koji izaziva ehinokokozu jednog organa: Echinococcus granulosus. Prema konsenzusu eksperata pod okriljem SZO-NRGE - SZO _ Neformalna Radna Grupa o Ehinokokozi je navela da bi tretman trebalo da bude: (1) perkutani tretman; (2) hirurgija, (3) anti-infektivni lekovi ili (4) pristup gledati i čekati ili kombinaciju navedenih.

Prikaz slučaja: Prezentovani slučaj je bio 7-godišni dečak bele rase, stanovnik ruralnog regiona blizu Tuzle, Bosna i Hercegovina, koji je prethodno imao istoriju asimptomatski uvećane jetre i male hidatidne ciste u plućima (multivisceralna ehinokokoza). Smatramo da je pacijent bio u fazi sekundarne hidatidoze čak i pre nego što je podvrgnut prvom tretmanu - PAIR metodi jetre i gde je nastavljeno sa dodatnom hemoterapijom. Dve nedelje nakon otpuštanja iz bolnice, dok je bio na dodatnoj hemoterapiji, imao je jednu od mogućih komplikacija, gde

\section{REFERENCES}

1. Sherwani RK, Abrari A, Jairarpuri ZS, Srivastava VK. Intracranial hydatidosis. Report of a case diagnosed on cerebrospinal fluid cytology. Acta Cytol. 2003; 47(3): 506-8.

2. Jairajpuri ZS, Jetley S, Hassan MJ, Hussain M..Hydatid disease in childhood: revisited report of an interesting case. J Parasit Dis. 2012; 36(2): 265-8.

3. Grozavu C, Ilias M, Pantile D. Multivisceral echinococcosis: concept, diagnosis, management. Chirurgia (Bucur). 2014; 109(6): 758-68.

4. Sumer A, Caglayan K, Altinli E, Koksal N. Casereport: Spontaneous liver hydatid cyst rupture in a child. Israel J Emerg Med. 2009; 9(1): 13-6.

5. Çelik T, Akçora B, Tutanç M, Yetim TD, Karazincir S, Ak2n MM, et al. Ruptured pulmonary hydatid cyst: a case report.Turkiye Parazitol Derg. 2012; 36(1): 45-7.

6. Siracusano A, Teggi A, Ortona E. Human cystic echinococcosis: old problems and new perspectives. Interdiscip Perspect Infect Dis. 2009; 2009: 474368.

7. Moro P, Scantz PM.Echinococcosis: a review. Int J Infect Dis. 2009; 13(2): 125-33.

8. Brunetti E, Kern P, Vuitton DA.Writing Panel for the WHO-IWGE Expert consensus for the diagnosis and treatment of cystic and alveolar echinococcosis in humans. Acta Trop. 2010; 114(1): 1-16.

9. Arif SH, Shams-Ul-Bari, Wani NA, Zargar SA, Wani MA, Tabassum R,et al. Albendazole as an adjuvant to the standard surgical management of hydatid cyst liver. Int J Surg. 2008; 6(6): 448-51. je došlo do zapaljenja prethodno formirane male hidatidne ciste, na čijem terenu je nastala apscesna masa i potencijalni rzik od sepse, koji je zahtevao hitnu hiruršku intervenciju i antibiotsku terapiju. Operacija i rani postoperativni tok su protekli normalno i pacijent je bio otpušten iz bolnice sa savetom da nastavi sa prethodno započetom dodatnom hemoterapijom (Albendazol) prema protokolu.

Zaključak: Većina inficiranih ljudi su asimptomatski i klinička manifestacija može da varira prema anatomskoj lokalizaciji ciste. S toga, mi želimo da ukažemo na značaj rutinske obrade ultrazvukom u dijagnostici pretškolske dece, kao i eventualnog rentgenskog nalaza. Ovaj prikaz slučaja naglašava značaj odabira adekvatnog tretmana, iako veličina ciste može biti irelevatna pri odlučivanju za operaciju kao prve linije odbrane, umesto konzervativnog lečenja.

Ključne reči: ehinokokoza, hidatidna cista, dijagnostika, lečenje.

10. Sumontra C, Philippe G, Adam M, Ahin B,Jay K. Images in Clinical Tropical Medicine About to Burst. Am. J. Trop. Med. Hyg. 2015; 92(3): 474-5.

11. Djuricic SM, Grebeldinger S, Kafka DI, Djan I, Vukadin M, Vasiljevic ZV. Cystic echinococcosis in children - the seventeen-year experience of two large medical centers in Serbia. Parasitol Int. 2010; 59(2): 257-61.

12. Cobzaru RG, Dumitrescu AM, Ciobotaru M, Rîpã C, Leon M, Luca M et al. Epidemiological aspects of hydatidosis in children, in some areas of north-eastern Romania. Rev Med Chir Soc Med Nat Iasi. 2013; 117(3): 754-7.

13. Paredes S, Torres J, Muena P, Schnettler D. Hepatopulmonary hydatidosis: pediatric case report and literature review. Medwave. 2014; 14(11): e6053.

14. Bobić B, Nikolić A, Radivojević SK, Klun I, Djurković-Djaković O. Echinococcosis in Serbia: an issue for the 21st century? Foodborne Pathog Dis. 2012; 9(11): 967-73.

15. Zargar-Shoshtari M, Shadpour P, Robat-Moradi N, Moslemi M. Hydatid cyst of urinary tract: 11 cases at a single center. Urol J. 2007; 4(1): 41-5.

16. Ammann RW, Eckert J.Cestodes: Echinococcus. Gastroenterol Clin N Am. 1996; 259(3): 655-89.

17. Sumer A, Caglayan KMD, Altini E, Koksal N. Case report: spontaneous liver hydatid cyst rupture in a child. Isr J Emerg Med. 2009; 9(1): 13-16.

18. Crepu C, Codreanu RR, Mastalier B, Popa LG, Cordo \} I, Beuran M, et al. Albendazole associated to surgery or minimallyinvasive procedures for hydatid disease - how much and how long. Chirurgia (Bucur). 2012; 107(1): 15-21. 
19. Horvat T, Grozavu C, Savu C, Cordo \} I, Nicodin A, VoivulescuV. Indicaåie abuzivã de tratament cu Albendazol în afecåiunitoracice neparazitare. Jurnalul de Chirurgie Toracicã. 1997; 2(3-4): 247-9.

20. Eckert J, Schantz P.M, Gasser R.P,et al. Geographic distributionand prevalence. In: Manual on Echinococcosis inhu- mans and animals: a public health problem of global concern. WHO/OIE, Paris, France. 2001; 100-42.

21. World Health Organization (W.H.O) InformalWorking Group. International classification ofultrasound images in cystic echinococcosis forapplication in clinical and field epidemiologicalsettings. Acta Tropica. 2003; 85: 253-61.

\section{Correspondence to / Autor za korespondenciju}

Zlata Hajric, MD,

Children's Department, General Hospital, Tesanj, Bosnia and Herzegovina,

Ul. Osmana Pobrica 17, Tesanj,

Phone number:+387 62560522.

E-mail: zlata.hajric@hotmail.com 